\title{
Batuque na cozinha a Sinhá não quer: imprensa, cultura e religiões afrobrasileiras
}

Silvana LOUZADA ${ }^{1}$

\begin{abstract}
Resumo:
O artigo trata de reportagens fotográficas sobre religiões espíritas publicadas no jornal carioca Última Hora na década de 1950. Analisa o esforço do jornal em ocultar a presença afro-brasileira nessas religiões, a promoção do embranquecimento dos cultos e o racismo implícito das reportagens. Traça um paralelo com a década de 1960, quando há uma relativa valorização dos ritmos de origem afro e com o momento atual, em que ocorre um recrudescimento na perseguição às Casas de Axé e a seus seguidores.
\end{abstract}

Palavras-chave: Fotojornalismo. Religiões de matriz africana. Discriminação religiosa. Racismo.

\section{The missus don't want no clangin' in the kitchen: press, culture and afrobrasilian religions}

\begin{abstract}
:
Hora in the 1950s. Analyzes the newspaper's effort to conceal the Afro-Brazilian presence in these religions, the promotion of the whitening of the worship services and the implicit racism of the reports. It draws a parallel with the 1960s, when there was a valorization of the afro rhythms and with the present moment, in which the persecution to the Axé Houses and their followers seems to be increasing.
\end{abstract}

Keywords: Photoperiodism. Afro-brasilian religions. Religious discrimination. Racism.

\section{La señora no quiere tambores en la cocina: prensa, cultura y religiones afrobrasileñas}

Resumen:

El artículo trata de reportajes fotográficos sobre religiones espiritistas publicados en la década de 1950 en Última Hora, periódico de Río de Janeiro. Analiza el esfuerzo del periódico para ocultar la presencia afrobrasileña en esas religiones, la promoción del blanqueamiento de los cultos y el racismo implícito de los informes. Traza un paralelo con la década de 1960, cuando hay una relativa apreciación de los ritmos de origen africano y con el actual momento, cuando hay un resurgimiento en la persecución de Casas de Axé y sus seguidores.

Palabras clave: Fotoperiodismo. Religiones afrobrasileñas. Prejuicio racial. Racismo.

Introdução

O artigo analisa a relação do fotojornalismo no jornal popular Última Hora $(U H)$ e as religiões espíritas na década de 1950 no Brasil. Procura mostrar, pela análise das

\footnotetext{
${ }^{1}$ Doutora em Comunicação pela Universidade Federal Fluminense, professora do Instituto Federal do Rio de Janeiro (IFRJ).E-mail: silvanalouzada@gmail.com
} 
imagens e do texto, o discurso racista e preconceituoso que se afirma num suposto realismo fotográfico. A fotografia, transformada em prova irrefutável, sustenta uma posição que visa o embranquecimento das religiões de matriz africana e uma suposta modernização desses cultos considerados primitivos.

\section{Estado e religião}

No Censo Demográfico de 1950, publicado em 1956 pelo Instituto Brasileiro de Geografia e Estatística (IBGE), declararam-se católicos romanos 93,49\% dos brasileiros, contra 3,35\% de protestantes e 1,59\% de espíritas ${ }^{2}$. Apesar da separação de Igreja e Estado no Brasil datar de 1890, persistiu a perseguição oficial aos cultos de matriz africana, referidos como "baixo espiritismo", e a seus seguidores, em sua maioria negros e de classes menos favorecidas. Em contraste com essas religiões estavam práticas abraçadas pelas classes mais altas, notadamente o espiritismo kardecista e suas variantes, conhecidas como espiritismo branco, de mesa ou científico, aceitas e praticadas por parte das classes médias e altas brancas, inclusive junto com o catolicismo.

O Código Penal de 1890, que vigorou até 1942, no artigo 157 elencava entre os "crimes contra a saúde pública": "Praticar o espiritismo, a magia e seus sortilégios, usar de talismans e cartomancias, para despertar sentimentos de odio ou amor, inculcar cura de molestais curaveis ou incuraveis, enfim, para fascinar e subjugar a credulidade publica" $[\mathrm{sic}]^{3}$ (BRASIL, 2004, p. 315). Já o artigo 158 dizia respeito à prática de curandeirismo, e o 156, ao exercício ilegal da medicina pelos diversos cultos (BRASIL, 2004). A revisão do Código Penal de 1940 manteve os artigos 156, 157 e 158, sendo incluídos no artigo 157 o "charlatanismo" como prática criminosa, e o novo artigo 27 , que criminalizava a exploração da credulidade pública mediante práticas relacionadas à feitiçaria (BRASIL, 1940).

As denominações de "linha branca" buscavam se diferenciar das matrizes de origem africana, como se vê na publicação de Mundo Espírita, de 2 de fevereiro de 1946, ao comentar um suicídio ocorrido em um centro espírita:

Noticiou a imprensa, com retumbância e não menor escândalo, a morte de uma
infeliz criatura levada ao suicídio dentro de um "Centro Espírita" sugestionada
pelo presidente do referido "Centro" onde se praticavam exóticas

\footnotetext{
${ }^{2}$ Registrava ainda $0,08 \%$ de ortodoxos; 0,13 de israelitas e $0,79 \%$ sem religião e sem declaração de religião (IBGE, 1956).

${ }^{3}$ Optou-se por manter a grafia original em todos os textos.
} 


\begin{abstract}
demonstrações espíritas sob impressionante ritual e estranhas formalidades [...] Para que assim não julguem os que Espiritismo não conhecem, aqui deixamos o nosso veemente protesto no tocante a classificação dada pela nossa imprensa leiga ao ambiente onde se reúnem alguns adeptos das chamadas "Linhas de Terreiro" onde alguns espíritos podem baixar em ambientes preparados com fumaça, canto e o apreciado parati. $\mathrm{O}$ que se pratica entre ambientes tais, não é Espiritismo. O lugar onde esse ambiente se estabelece, não é um "Centro Espírita” (MUNDO ESPÍRITA, 1946 apud OLIVEIRA, 2014, p. 158).
\end{abstract}

A disputa pela denominação espírita passava pela diferenciação das práticas toleradas pelos mais abastados das abraçadas pelas parcelas populares e negras da população.

Durante o Estado Novo ${ }^{4}$ houve uma relativa valorização de manifestações culturais populares, embaladas pelo conceito de democracia racial que teve Freyre (2003) como um de seus teóricos. Essa democracia jamais existiu e o conceito foi usado para mascarar o racismo estrutural no país, mas alguns fatos contribuíram para a naturalização do conceito. Em 1934 foi fundada a União Geral das Escolas de Samba do Brasil. Em 1953, no segundo governo Vargas ${ }^{5}$, a capoeira do Mestre Bimba realizou uma apresentação para o presidente Vargas, que a classificou de "único esporte verdadeiramente nacional" (MELLO, 2002, p. 6).

Embora o discurso oficial prezasse a tolerância e ainda catapultasse a Umbanda a culto genuinamente brasileiro, por contemplar as três raças, na prática a perseguição religiosa aos cultos mediúnicos continuaria até o final da ditadura, em 1945, e não desapareceria nos anos seguintes. O chefe de polícia do Distrito Federal, Filinto Müller, exigia o registro dos centros espíritas na Delegacia Política, alegando que os terreiros davam abrigo a comunistas, justificando com isso a repressão policial em todo o país (MAGGIE, 1992).

Em 1952 a Igreja Católica, alarmada com o crescimento da Umbanda e demais cultos mediúnicos, criou o Secretariado Nacional de Defesa da Fé, no âmbito da Conferência Nacional dos Bispos do Brasil (CNBB), com o objetivo de enfrentar o crescimento do número de fiéis daqueles cultos (ISAIA, 1998).

\footnotetext{
${ }^{4}$ Terceira e última fase da Era Vargas, inspirado no modelo nazifascista (1937-1945) (FAUSTO, 2009).

${ }^{5}$ Deposto em 1945, em 1951 Vargas retornou à Presidência da República por votação popular (FAUSTO, 2009).
} 


\title{
Imprensa e terreiros na década de 1950
}

Em 1955 o jornal Última Hora dedicou reportagens fotográficas aos cultos que proliferavam em terreiros da capital da República e da Baixada Fluminense.

Fundada em 1951 por Samuel Wainer, Última Hora foi um jornal popular que inovou na apresentação da fotografia e no seu uso como ferramenta de mobilização popular e de instrumento de barganha no cenário político. Sedimentou novos parâmetros para o fotojornalismo diário na utilização de sequências fotográficas, na publicação regular da cor e na exploração do poder noticioso da fotografia.

Em 9 de fevereiro de 1954 foi publicada a primeira matéria examinada neste estudo, sobre os cultos espíritas, trazendo na primeira página a foto de três iaôs ${ }^{6}$ e um texto irônico:

\begin{abstract}
A baiana montou uma exótica fábrica de "Aiôs" - "Cada matéria traz uma predestinação quando vem à Terra" - Receita para ficar Babalorixá: Raspar a cabeça até ficar no toucinho, pintar depois de massa branca (fazendo o "paralitimpim") e passar quinze dias no "come-e-dorme" - uma denúncia de vizinhos levou a Polícia à estranha seita (“-SOU CABOBLO...", 1954, p. 1).
\end{abstract}

As iaôs foram fotografadas na delegacia de polícia, com pintura branca e roupas rituais. Há ainda uma foto com detalhe do rosto de uma das "alunas da "professora", acompanhada do comentário do jornal sobre o ritual e a "estranha seita" que levou a vizinhança a chamar a polícia:

\begin{abstract}
O mais sério, complicado e hermético ritual de "Umbanda", vulgarmente conhecido nos "carimbas" ou candomblés por "fazer santo" foi sacrilegamente desvendado, ontem em flagrante desrespeito às rígidas leis bantus quando estas três "iaôs" ("filhas de santos") ficaram expostas, ainda atuadas, na delegacia do $21^{\circ}$ Distrito. Segundo os crentes a "babalorixá" sofrerá duro castigo ("-SOU CABOBLO...”, 1954, p. 1).
\end{abstract}

As fotografias e a menção ao castigo remetem a duas fotorreportagens polêmicas publicadas em 1951. Em 12 de maio a revista Paris Match publicou uma reportagem do cineasta francês Henri-Georges Clouzot tratando o candomblé da Bahia de forma preconceituosa e o transe religioso como doença mental. Já a revista brasileira $O$ Cruzeiro publicou, em 15 de setembro de 1951, reportagem de Arlindo Silva, com fotos de José

\footnotetext{
${ }^{6}$ Iaô: termo de origem iorubá. Designa a filha de santo iniciante, médium feminina no primeiro grau de desenvolvimento no Terreiro (RABELO, 2015).
} 
Medeiros, intitulada "As noivas dos deuses sanguinários". As duas reportagens traziam fotos de rituais do candomblé que não deveriam tornar-se públicos (TACCA, 2009).

As religiosas teriam sido castigadas após a publicação da reportagem de $O$ Cruzeiro. Segundo Medeiros (apud TACCA, 2009, p. 23), "as iaôs não tiveram sua iniciação reconhecida e assim ficaram marginalizadas dentro da religião, com consequências graves para elas, uma suicidou-se anos depois e outra foi internada no hospital psiquiátrico" e "a mãe-de-santo teria sido assassinada um ano depois". Porém, Tacca (2009) desmonta essa versão trágica, já que duas delas, a mãe-de-santo e uma das iaôs, permaneceram na religião por toda vida.

Figura 1 - Jornal Última Hora, 9 de fevereiro de 1954, p. 1.
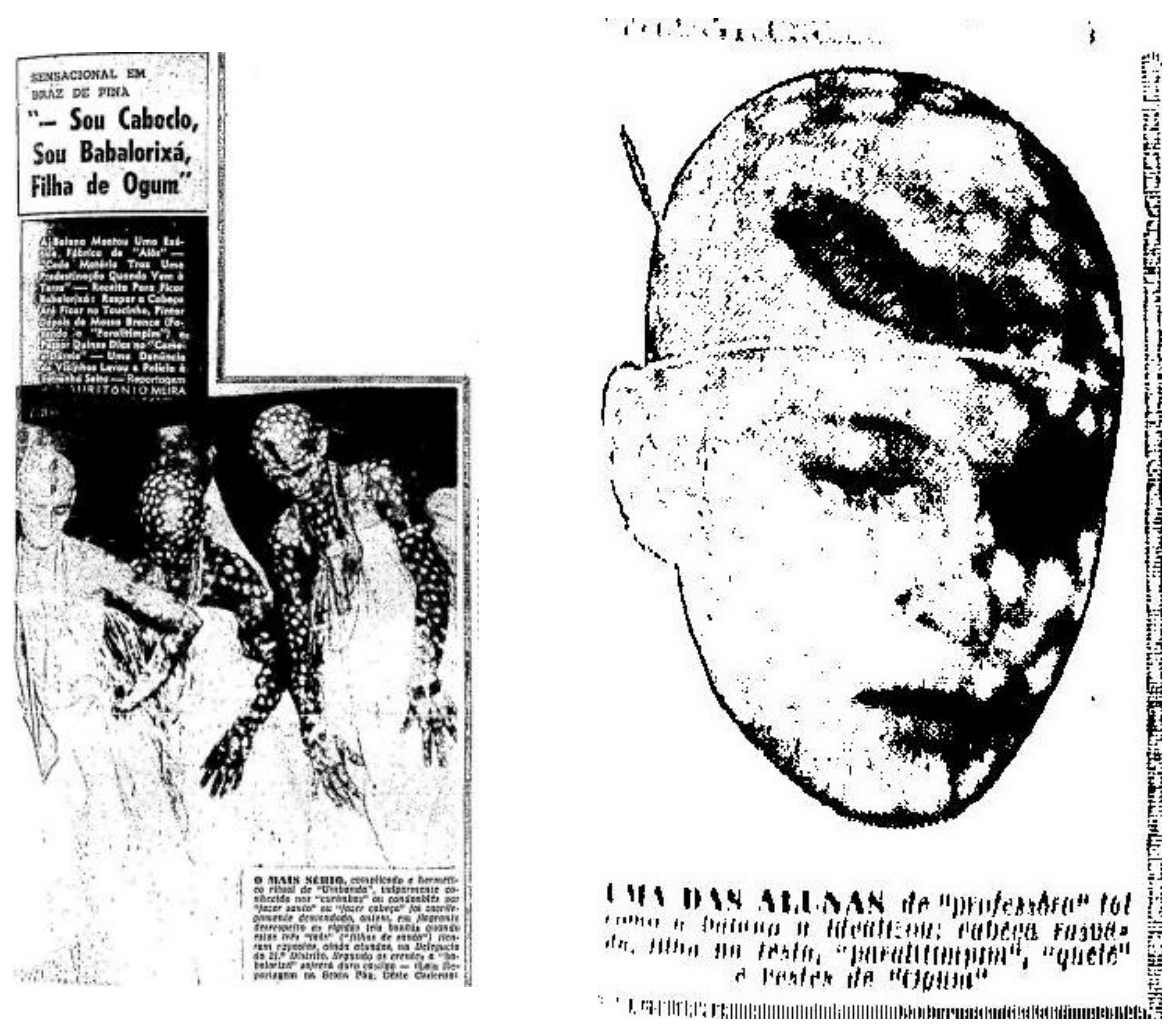

Fonte: Hemeroteca Nacional Digital da Biblioteca Nacional.

Devido à importância de $O$ Cruzeiro, é certo que as fotos e seu enredo eram conhecidos pelos autores da reportagem de Última Hora. Mas, mesmo que o fotógrafo tenha se inspirado nas imagens de Clouzot e de Medeiros, elas foram realizadas em ambientes muito diferentes: as primeiras dentro de terreiros de Camdomblé; a última, em uma delegacia policial no subúrbio carioca, retratando as iaôs detidas e humilhadas, o que é reforçado pelo texto. 


\section{Fotorreportagens de Última Hora}

Imagens do outro, cheias de preconceitos e estereótipos, minam a ideia de que o testemunho das imagens é digno de ser levado a sério. O que se documenta é um encontro cultural e as respostas dadas a esse encontro pelos membros de uma determinada cultura. Se a visão do outro é determinada por ideias preconcebidas e estereotipadas, a visão do eu que essas imagens implicam é ainda mais indireta. As imagens não dão acesso diretamente ao mundo social, mas às construções imaginadas que determinada parcela da sociedade tem do outro.

Uma das reações dos grupos que enfrentam outras culturas é negar ou ignorar a distância cultural, assimilar os outros a nós mesmos por meio da analogia. O outro é visto como o reflexo do eu e a analogia que torna o exótico inteligível, o domestica (BURKE, 2005). Outra reação possível é a invenção, consciente ou inconsciente, de uma cultura oposta à sua própria.

A sátira e o estranhamento deram o tom na matéria da prisão das iaôs, viés menos evidente na série de reportagens que Última Hora publicou durante o mês de outubro de 1955, intitulada “O Espiritismo visto a sério". Em 17 de outubro, o jornal destacava: “Impressionante documentário fotográfico dos 'terreiros' e 'tendas' espalhados pelo Rio!". O texto ressaltava que milhares de pessoas "de todas as classes" procuravam esses locais de culto, e completava: "O fato existe - eis a prova - (reportagem de Eloy Dutra Fotos de Jankiel)".

Com chamada na primeira página, a prova estaria na página 12 , com nove fotografias de diferentes cultos espíritas retratados em uma "página gráfica com aspectos sensacionais e inéditos colhidos pela reportagem fotográfica" (DUTRA, 1955c, p. 12). O destaque era para “a bela sacerdotisa da 'Irmandade Estrêla D'Alva' no trono espiritual em que recebe 'Wandu', o deus indu-chinês, protetor e guia da irmandade" (DUTRA, 1955c, p. 12). A mulher branca, posando recostada em uma poltrona, olhava para o alto, com roupas claras e um véu branco na cabeça.

A foto seguinte traz uma "moça de pele diáfana e unhas polidas", cabelos claros e um charuto na boca. A chamada ressalta sua pele, "diáfana", ou seja, que possibilita a passagem da luz, translúcida: uma pele clara. O charuto, destoante, estava na sua boca não por desejo próprio, mas porque o “"caboclo’ exige” (DUTRA, 1955c, p. 12). Ao lado vinha a fotografia do "prêto Bernardino [que] é chefe dos 'Cambonos' dos 'Pequeninos 
de Umbanda'. Tem lá o seu aspecto de rei africano e muita moça bonita de Copacabana vai à tenda em busca de seus conselhos" (DUTRA, 1955c, p. 12, grifo nosso).

É clara a disparidade no tratamento que o texto dá às mulheres brancas e ao homem negro, e também nas imagens o contraste é gritante. A "bela sacerdotisa” apareceu rodeada por móveis luxuosos, sentada em um trono, e a loura de pele diáfana, sem olhar para a câmera, foi retratada com um fundo neutro. Já "prêto Bernardino" tinha um olhar grave e fixo na câmera, numa tomada de baixo para cima e com o fundo carregado de objetos como vela, estátuas de santos e plantas. O fundo carregado de elementos colabora para a poluição visual da imagem, contrastando com a limpeza da foto das mulheres brancas.

Preto Bernardino foi o único negro com destaque na série. Ao lado de sua foto há a tomada de um culto umbandista com três pessoas brancas ao centro. A legenda descreve: “acendendo o charuto de 'Pai João'. Em sinal de respeito, todos se curvam ante o 'espírito' presente do prêto velho, que atende indistintamente ricos e pobres" (DUTRA, 1955c, p. 12). O texto destaca que o preto velho está lá em espírito e a foto mostra que está encarnado em um corpo branco. O respeito dos fiéis era para o espírito do preto velho, mas as reverências eram feitas para um corpo físico branco.

Há ainda o "Presidente da “Tenda São Jerônimo"”, Sr. Alvarez Passos, fotografado em postura de oração junto a uma imagem de São Jerônimo. De terno e óculos, tinha nome e sobrenome e recebia o tratamento de "Senhor", bem diferente do "prêto Bernardino". O Sr. Alvarez Passos ficaria ainda mais distante do "chefe dos "Cambonos"” se levarmos em conta que Jerônimo é o santo doutor, tido como o maior conhecedor da Bíblia nos primeiros tempos do cristianismo, sempre representado com livros. Um santo intelectual.

São três fotos da Tenda São Jerônimo. Uma em que "parte das centenas de médiuns [...] iniciam o trabalho de incorporação" e outra da "fila" em que "gente de todas as classes sociais vai conversar com o "médium' incorporado" (DUTRA, 1955c, p. 12). $\mathrm{Na}$ primeira, todos eram homens brancos. Na segunda, os fiéis são também brancos e a única negra é a médium que dava um passe $\mathrm{em}^{7}$ uma mulher branca e bem vestida.

A documentação fotográfica trazia ainda a foto de uma mulher branca, com os olhos fechados e cachimbo na boca, com a mão sobre a cabeça de um homem também

\footnotetext{
${ }^{7}$ Imposição de mãos para transmitir energias (MOURA, 2004).
} 
branco e a legenda: "'Prêto velho' desceu numa moça branca e está dando um 'passe' [...]” (DUTRA, 1955c, p. 12).

A busca por vulgarizar os rituais espíritas para um público mais amplo vinha acompanhada da necessidade de afirmar, no texto e na imagem, que os cultos atraíam pessoas de classes sociais mais altas, num claro processo de domesticação dessas religiões. O procedimento ocorria em duas frentes: de um lado, o embranquecimento e universalização das classes sociais que os frequentavam; de outro, a generalização das diversas religiões, fossem de origem europeia, oriental ou de matriz africana. Práticas que pudessem causar desconforto aos leitores, como os sacrifícios animais, não eram retratados.

O jornal apelava para a irrefutabilidade da prova fotográfica e apresentava a série como "um esforço jornalístico inédito na história de nossa imprensa não só pela sua objetividade, como também por ser esta a primeira vez que tais fatos são revelados documentalmente, através de testemunhos insuspeitos [...]” (DUTRA, 1955a, p. 1). Última Hora não apenas se autoatribuía objetividade e isenção, mas também se respaldava na fotografia: "os fatos e as fotos aqui estão" (DUTRA, 1955a, p. 1, grifo nosso).

O mesmo discurso foi repetido na edição de 17 de outubro de 1955, quando diz apresentar "uma cobertura inédita na imprensa carioca estudando com objetividade" o espiritismo, que seria "um fato inconteste, concreto", para questionar, a seguir, "onde reside a razão suprema dessa crendice" (DUTRA, 1955c, p. 12, grifo nosso). 
Figura 2 - Jornal Última Hora, 17 de outubro de 1955, p. 12.



Fonte: Hemeroteca Nacional Digital da Biblioteca Nacional.

Ao agrupar sob o rótulo de crendice cultos tão diversos, o jornal construía um espírita estereotipado e o padronizava, tornando-o mais palatável. Contribuía para isso mostrar a variedade do público que circulava pelos centros espíritas, onde havia "gente bem", ex-padres, belas mulheres.

Reforçando o caráter documental das reportagens, o repórter, não apenas por uma suposta objetividade jornalística, mas também por preconceitos mal disfarçados, fazia 
questão de declarar que comparecia aos centros por "dever profissional". Por não fazer parte daquele mundo, estaria habilitado a dar seu testemunho sobre as "coisas quase inacreditáveis" que presenciara (DUTRA, 1955e, p. 1).

Nem o exato nem o verdadeiro são inerentes à fotografia e é necessário entender porque as fotografias-documentos que são construídas, convencionais e mediadas, aparentam ser realistas, imediatas, exatas e verdadeiras (ROUILLÉ, 2009). Imagens fotográficas são parte de um combate ideológico (ROSLER, 2007), que envolve disputas de imaginários, ideologias e crenças, e colocam a questão do poder, já que as representações não são unânimes ou consensuais.

O uso da fotografia como arma no combate ideológico foi percebido muito cedo em jornais que, como Última Hora, investiram na linguagem fotográfica. Era preciso assegurar que "o repórter é testemunha” (IMPRESSIONANTE..., 1955, p. 12) quando a fotografia o colocava frente a frente com o sacerdote espírita. Milagres não são fotografados e não há como reproduzir em imagens o poder dos médiuns. Benjamin (1994, p. 107) sugere que, em momentos como esses, “deve intervir a legenda, introduzida pela fotografia para favorecer a literalização de todas as relações da vida e sem a qual qualquer construção fotográfica corre o risco de permanecer vaga e aproximativa". E, como comenta Sontag (2003, p. 14), "todas as fotos esperam sua vez de serem explicadas ou deturpadas por suas legendas".

Quando Última Hora se propõe a levar a sério o espiritismo, sutilezas etnocêntricas, realismo fotográfico e a credibilidade do repórter destacam as contradições sociais refletidas pelo jornal, apresentadas como a pura transcrição da verdade, do real que se escondia nas tendas e terreiros da cidade.

Em outra reportagem, o protagonista que "largou a batina para abraçar o espiritismo" era também capaz de realizar "coisas de estarrecer" (DUTRA, 1955d, p. 1). Além da imagem do médium com a mão no rosto indicando um transe mediúnico, havia a foto de uma "bela jovem" em êxtase, recebendo um passe de uma médium negra, quase totalmente de costas para a câmera. Não era possível retratar "a força espiritual" que libertava a moça dos "elementos negativos do plano invisível”, mas a imagem da jovem branca e bem vestida, com boca aberta e olhos para o alto, cumpria a tarefa de transmitir a grandeza daquele momento espiritual, enquanto seu status social colaborava na domesticação de culto.

Em 11 de outubro de 1955, outra mulher branca, jovem e bem vestida curvava-se diante de uma negra que lhe segurava as mãos. A "grã-fina" branca é a "gente-bem" e a 


\section{REVISTA BRASLLEIRA DE HISTÓRIA DA MÍDIA}

aparente tranquilidade na relação entre as mulheres e o comedimento do ambiente amenizavam as informações do texto, que relatava que a “'medium' bebeu seis garrafas de cachaça e continuou a dançar normalmente!” (DUTRA, 1955b, p. 1).

Figura 3 - Última Hora, 27/10/1955 primeira página

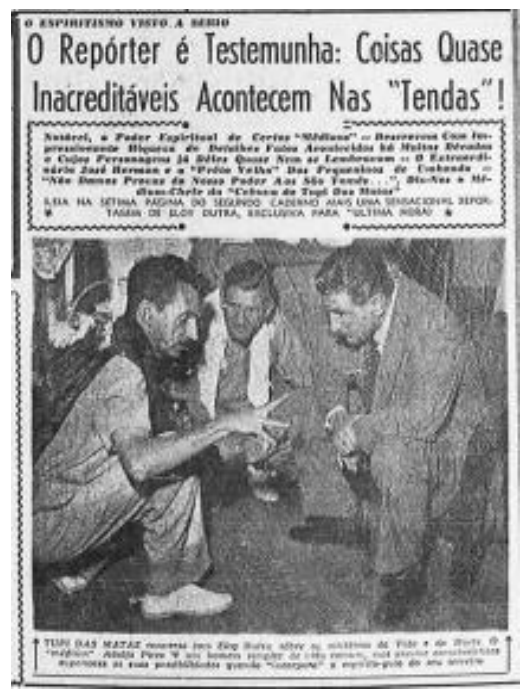

Figura 5 - Última Hora, 11/10/1955 primeira página

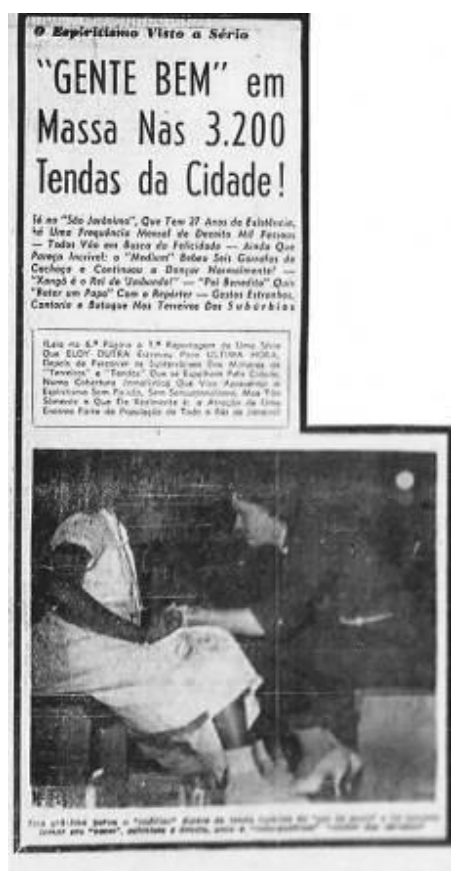

Figura 4 - Última Hora, 20/10/1955 -

primeira página

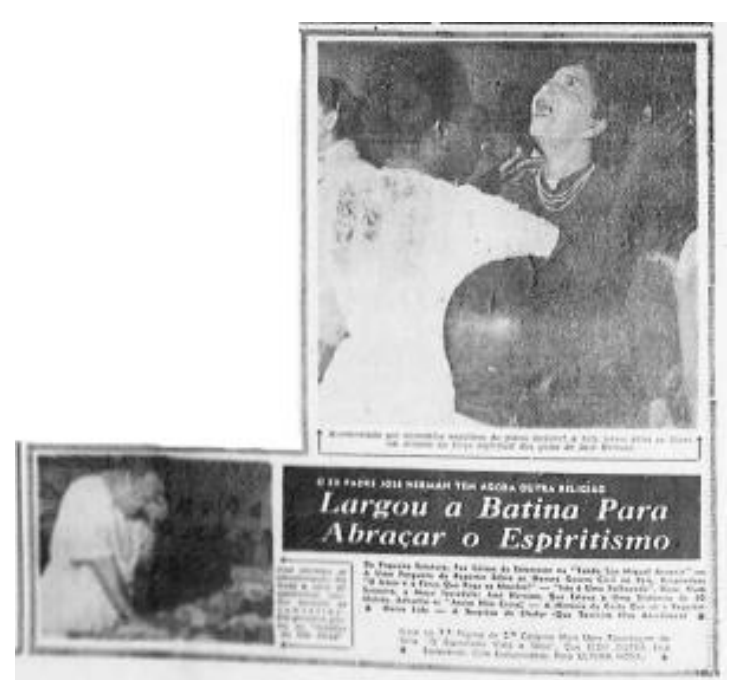

Figura 6 - Última Hora, 22/10/1955 primeira página, fotos Jankiel

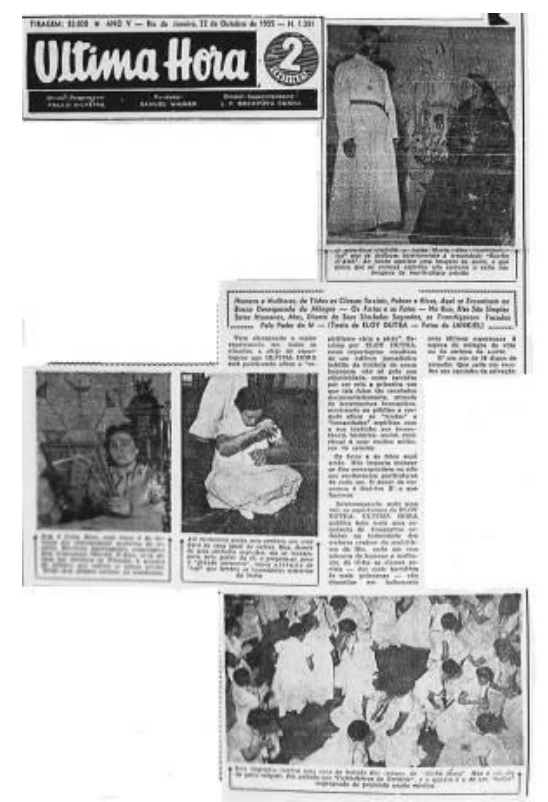

Fonte: Hemeroteca Nacional Digital da Biblioteca

Nacional.

Jaguaribe e Lissovsky (2007, p. 89) destacam a secularização do invisível, ocorrida com a modernização da cultura e das sociedades: "O domínio do invisível, antes 
associado ao oculto, ao misterioso e ao mágico, tornava-se um novo território desencantado virtualmente anexável ao visível graças ao desenvolvimento da ciência e da técnica". A fotografia teria exercido um importante papel nesse processo de desvelamento do mundo por sua característica de não apenas representar o mundo visível, mas também de torná-lo visível.

A fotografia não está associada apenas ao passado, mas traz em si também um futuro, como expectativa do que a imagem viesse a figurar. A definição do cenário, a inclusão ou exclusão dos protagonistas são estratégias pedagógicas do olhar, que têm a capacidade de tornar "visíveis modernidades imaginadas" (JAGUARIBE; LISSOVSKY, 2007, p. 90). E era pelas ausências que Última Hora construía em suas páginas o lugar de uma nova e moderna religiosidade espírita, onde não havia sacrifícios animais e o público não era pobre, nem negro, livre das práticas primitivas e de fiéis exóticos.

E até que ponto o embranquecimento não seria também uma estratégia de sobrevivência cultural dos próprios membros das religiões? A Umbanda, surgida no início do século $\mathrm{XX}$, propalava ser a única religião genuinamente brasileira, pois reuniria elementos ameríndios, africanos e europeus (DIAS, 2011). Ortiz (1999) assinala que ocorreu não apenas o embranquecimento das religiões de origem africana e ameríndia, mas também o movimento contrário, de empretecimento do kardecismo e demais religiões científicas. Para o autor, ao assumir a linguagem científica, a Umbanda se distanciava deliberadamente dos cultos de origem africana, buscando aceitação na sociedade.

Assim, as reportagens de Última Hora cumpriam um duplo papel: se, por um lado, projetavam a imagem de um futuro religioso nacional branco, moderno e urbano, por outro, reforçavam para o público e para os religiosos um novo pertencimento, dissociado da herança negra e escrava.

\section{Considerações finais}

Em 1968, João da Baiana, Pixinguinha e Clementina de Jesus, negros célebres no cenário musical brasileiro, lançaram o LP Gente da Antiga, produzido por Hermínio Bello de Carvalho, produtor branco, reconhecido no meio cultural negro e popular. O panorama cultural do período era diferente do de há 13 anos, quando Última Hora publicou as séries de reportagens: o país testava a valorização da cultura negra e popular, ainda que de forma folclorizada. Nesse disco, João da Baiana gravou sua música inédita, composta em 1917, cujo título este artigo tomou emprestado. 
Diz um trecho: "Não moro em casa de cômodo / Não é por ter medo não / $\mathrm{Na}$ cozinha muita gente / Sempre dá em alteração / Mas o batuque na cozinha sinhá não quer / Por causa do batuque eu quebrei meu pé" (BATUQUE..., 1968). A canção alude às relações entre brancos, negros e mulatos, perseguição policial e ao estigma de morar em casa de cômodos ${ }^{8}$.

As relações de poder estabelecidas e as estratégias de sobrevivência dos diversos grupos, hegemônicos ou não, sofreram significativas transformações desde a composição da canção, a publicação das reportagens analisadas e os anos 1960, quando o batuque não era mais proibido, como era na infância do compositor, neto de escravos. A cena cultural do final dos anos 1960 valorizava a música e algo da cultura de origem negra. Em 1966, Vinicius de Moraes $^{9}$, poeta e diplomata branco de classe média alta, lançou, em parceria com Baden Powell, o disco Os afro-sambas, um dos melhores de sua carreira. Boa parte das músicas do álbum fala de Orixás e mistura instrumentos comuns ao samba, como pandeiros e agogôs, com atabaques de Candomblé.

O batuque dos terreiros agora era um ritmo na moda na Zona Sul do Rio de Janeiro, a capital cultural do país. Finalmente, ritmos de origem africana entravam pela porta da frente de teatros e casas de show. Mas o reconhecimento desses ritmos não resultou na aceitação das religiões que lhe deram origem, embora contribuísse para legitimar os seus membros e fortalecê-los como sujeito coletivo.

Ao final da segunda década do século XXI, na cidade de João da Baiana, onde as iaôs foram presas, Última Hora publicou a série de reportagens e Vinicius de Moraes viveu e compôs suas músicas e poemas, terreiros são incendiados e vandalizados. $\mathrm{O}$ prefeito da cidade, bispo de uma igreja neopentecostal fundamentalista e sectária, promove perseguição às doutrinas de matriz africana.

O batuque saiu da cozinha para as casas de espetáculo, mas o racismo e a perseguição às Casas de Axé, onde o ritmo se originou, persiste.

\section{Referências}

BATUQUE na cozinha. Intérpretes: Pixinguinha, Clementina de Jesus, João da Bahiana. Compositor: João da Bahiana. In: GENTE da antiga. Intérpretes: Pixinguinha, Clementina de Jesus, João da Bahiana. [S.1.]: Odeon, 1968. 1 disco vinil, lado B, faixa 3.

\footnotetext{
${ }^{8}$ Casas de cômodos, ou cortiços, são habitações populares coletivas onde vivem várias famílias de baixa renda, dividindo a infraestrutura externa, como banheiros, cozinha e lavanderia.

${ }^{9}$ Compositor, com Tom Jobim, da música Garota de Ipanema.
} 
BENJAMIN, Walter. Pequena história da fotografia. In: BENJAMIN, Walter. Magia e técnica, arte e política: ensaios sobre literatura e história da cultura. São Paulo: Brasiliense, 1994. p. 91-107. (Obras Escolhidas, v. 1).

BRASIL. [Código penal (1890)]. Código penal da República dos Estados Unidos do Brasil. Organizado por Oscar de Macedo Soares. Ed. fac. similar. Brasília: Senado Federal: Superior Tribunal de Justiça, 2004. (Coleção história do direito brasileiro. Direito penal; 6). Disponível em: http://www2.senado.leg.br/bdsf/handle/id/496205. Acesso em: 21 jan. 2020.

BRASIL. Decreto-Lei n. 2848, de 7 de dezembro de 1940. Institui o Código Penal. Rio de Janeiro, 1940. Disponível em:

https://www2.camara.leg.br/legin/fed/declei/1940-1949/decreto-lei-2848-7-dezembro1940-412868-publicacaooriginal-1-pe.html. Acesso em: 21 jan. 2020.

BURKE, Peter. Visto y no visto: el uso de la imagen como documento histórico. Barcelona: Crítica, 2005.

DIAS, Rafael de Nuzzi. Correntes ancestrais: os pretos-velhos do Rosário. 2011. Dissertação (Mestrado em Psicologia) - Faculdade de Filosofia, Ciências e Letras de Ribeirão Preto, Universidade de São Paulo, Ribeirão Preto, 2011. doi:10.11606/D.59.2011.tde-07082011-105621. Acesso em: 21 jan. 2020

DUTRA, Eloy. Êles estão à procura de Deus. Última Hora, Rio de Janeiro, p. 1, 22 out. 1955a.

DUTRA, Eloy. "Gente bem” em massa nas 3.200 tendas da cidade! Última Hora, Rio de Janeiro, p. 1, 11 out. 1955 b.

DUTRA, Eloy. Impressionante documentário fotográfico dos "terreiros" e "tendas" espalhados pelo Rio! Última Hora, Rio de Janeiro, p. 12, 17 out. 1955c.

DUTRA, Eloy. Largou a batina para abraçar o espiritismo. Última Hora, Rio de Janeiro, p. 1, 20 out. 1955d.

DUTRA, Eloy. O repórter é testemunha: coisas quase inacreditáveis acontecem nas “tendas". Última Hora, Rio de Janeiro, p. 1, 27 out. 1955e.

FAUSTO, BORIS. História do Brasil. São Paulo: EDUSP, 2009.

FREYRE, Gilberto. Casa grande \& senzala: formação da família brasileira sob o regime patriarcal. São Paulo: Global, 2003.

IBGE. Censo demográfico 1950. Rio de Janeiro: IBGE, 1956. Disponível em https://biblioteca.ibge.gov.br/visualizacao/periodicos/20/aeb 1950.pdf. Acesso em: 21 jan. 2020.

IMPRESSIONANTE documentário fotográfico dos "terreiros" e "tendas" espalhados pelo Rio! Última Hora, Rio de Janeiro, p. 12, 17 out. 1955. 
ISAIA, Artur César. Catolicismo versus umbanda: lutas de representação e identidade nacional (senzala delenda est). Revista de Ciências Humanas. Florianópolis, v. 16, n. 24, p. 28-42, out. 1998.

JAGUARIBE, Beatriz; LISSOVSKY, Maurício. O visível e os invisíveis: fotografia e imaginário social no Brasil. In: JAGUARIBE, Beatriz. O choque do real: estética, mídia e cultura. Rio de Janeiro: Rocco, 2007. p. 89-109.

MAGGIE, Yvone. Medo e feitiço: relações entre magia e poder no Brasil. Rio de Janeiro: Arquivo Nacional, 1992.

MELLO, André da Silva. A história da capoeira: pressuposto para uma abordagem na perspectiva da cultura corporal. In: VIII CONGRESSO BRASILEIRO DE HISTÓRIA DA EDUCAÇÃO FÍSICA, ESPORTE, LAZER E DANÇA, 8., 2002, Ponta Grossa, PR. As ciências sociais e a história da educação física, esporte, lazer e dança. Ponta Grossa/PR: Universidade Estadual de Ponta Grossa, 2002.

MOURA, Marta Antunes. Estudo sobre o passe: o passe nas reuniões mediúnicas. Brasília: Federação Espírita Brasileira, 2004.

OLIVEIRA, Marco Aurélio Gomes de. Imprensa espírita na cidade do Rio de Janeiro: propaganda, doutrina e jornalismo - (1880-1950). 2014. Dissertação (Mestrado em História) - Departamento de História, Universidade Federal Fluminense, Niterói, 2014.

ORTIZ, Renato. A morte branca do feiticeiro negro. São Paulo: Brasiliense, 1999.

RABELO, Miriam C. M.. Aprender a ver no candomblé. Horizontes

Antropológicos, Porto Alegre, v. 21, n. 44, p. 229-251, jul./dez. 2015. Disponível em: http://www.scielo.br/scielo.php?script=sci_arttext\&pid=S010471832015000200229\&lng=en\&nrm=iso e http://dx.doi.org/10.1590/S010471832015000200010. Acesso em: 21 jan. 2010.

ROSLER, Martha. Imágenes públicas: la función política de la imagen. Barcelona: Gustavo Gili, 2007.

ROUILLÉ. A fotografia: entre documento e arte contemporânea. São Paulo: Editora Senac, 2009.

SONTAG, Susan. Diante da dor dos outros. São Paulo: Companhia da Letras, 2003.

“-SOU CABOBLO, sou babalorixá, filho de Ogum”. Última Hora, Rio de Janeiro, p. 1, 9 fev. 1954.

TACCA. Fernando Cury de. Imagens do sagrado: entre Paris Match e $O$ Cruzeiro. Campinas, SP: Editora Unicamp, 2009.

Submetido em: 09/10/2019

Aprovado em: 30/10/2019 